\title{
Eckart Otto's contribution to the question of the composition of the Sinai pericope: An appreciation
}

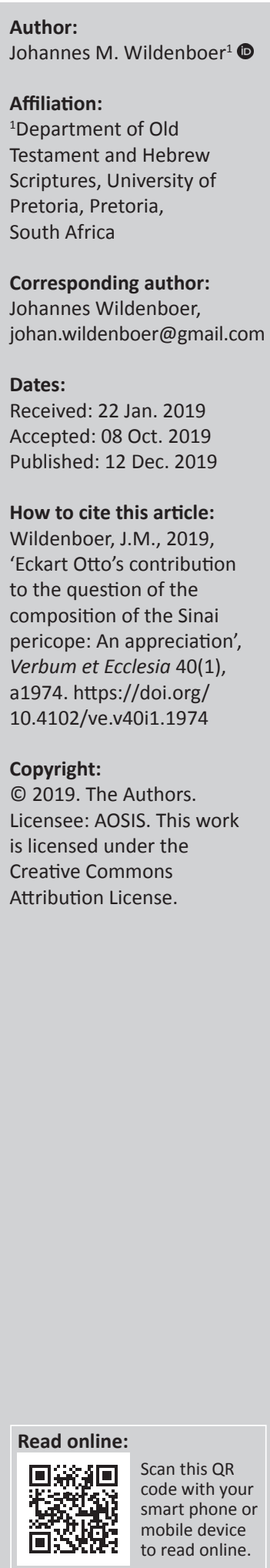

\begin{abstract}
The composition of the Sinai pericope presents the reader with several literary problems, with specific reference to the incoherence of the text caused by textual irregularities in the sense of time, genre and theological issues. The chronological issues have led to the proposal that the legal codes (The Decalogue and Covenant Code) were interpolated into a broader narrative framework. Several scholars have attempted to unravel the Sinai pericope with diachronic or synchronic tools. This article investigates several solutions in order to understand Eckart Otto's contribution to the current debate.

Intradisciplinary and/or interdisciplinary implications: This article engages literary criticism and hermeneutics to evaluate Eckart Otto's solution in the broader framework of the history of research.
\end{abstract}

Keywords: Eckart Otto; Sinai pericope; synchronic; diachronic; law; narrative.

\section{Introduction}

The Pentateuch exhibits a perplexing mixture of narrative and law. The book of Genesis contains narrative, and so does the early part of Exodus. From Exodus 20, where the Decalogue is introduced, we find the emergence of large sections of law. This culminates in the book of Deuteronomy, where legal statues are framed by exhortations to keep the law. In this article, this question of the relationship between law and narrative in the context of the Sinai pericope (Ex 19-24) is discussed. ${ }^{1}$ The proponents of source criticism have noted that the Sinai pericope fits loosely into the present context, and consequently they argue that it was interpolated into the surrounding narrative. This observation is based on literary-critical grounds. ${ }^{2}$ Other scholars propose that the mixture of law and narrative form a cohesive unit. They base their work on synchronic studies to prove that the Sinai pericope reads smoothly without textual issues or constraints. In this article, both these cases are stated carefully. Then Eckart Otto's solution to this problem is presented and his proposal against other solutions is evaluated. ${ }^{3}$

\section{The Sinai pericope (Ex 19-24) as interpolation}

Wellhausen (1899) already noted the tension and irregularities in Exodus 19-24. In the parlance of the developing source criticism, he attributed the Exodus 19-24 to three sources (Wellhausen 1899:88). According to Wellhausen's careful and comprehensive analysis, the Yahwist (J) was responsible for the narratives about Moses' ascent up Mount Sinai during the theophany (Ex 19:20-25; 21-23; 24:3-8). The Elohist (E) was responsible for the theophany itself (Ex 19:10-19) as well as the Decalogue (Ex 20:1-19) and some other miscellaneous verses (Ex 24:1-2, 9-14). The Covenant Code (Ex 20:22-23:33) belongs to J. In Wellhausen's analysis, the priestly source (P) is only responsible for the introduction to the narrative (Ex 19:1-2a). Wellhausen takes this proposal further by arguing that a 'Jehowist redactor' with some relationship to Deuteronomic tradents combined J and $\mathrm{E}$ into a comprehensive narrative. This redaction formed the basis of Wellhausen's (1957:346)

1.In the context of this article, the term 'Sinai pericope' refers specifically to Exodus 19-24, which contains the Decalogue and the Covenant Code. I am aware of the fact that several scholars use this term in a broader sense to refer to Exodus 19 to Numbers 10.

2.For instance, the Covenant Code seems to interrupt the narrative. Therefore, Hyatt (1971:197) and Noth (1962:154) have argued that the Decalogue originally followed Exodus 20:18-21 and was therefore inserted into the current narrative. Eissfeld (1965:213-219) and Boecker (1980:130) took this argument further by proposing that the whole of the Covenant Code (Ex 20:22-23:33) was inserted into the present narrative.

3.Otto's proposal dictates that the Covenant Code was inserted into the Sinai pericope. Therefore, Otto 's proposal can also fall into this first category. However, Otto blends diachronic and synchronic approaches in a rather unique way, and therefore his proposal will be discussed separately. 
proposal that the concept of lawgiving in the Sinai pericope originated in post-exilic times with the priestly author $(\mathrm{P})$.

Wellhausen's hypothesis drew important conclusions that subsequent scholars would expand. Firstly, the observation that the Sinai pericope was inserted into the surrounding narrative. According to Wellhausen, the original narrative represents a tradition in which Israel went from the foot of the mountain to Kadesh, where they stayed for 40 years. In other words, the sojourn to Sinai was not originally a part of the narrative (Wellhausen 1894:12). He would reach a further conclusion, namely that Mount Sinai was originally interpreted as the dwelling of the deity, and that it was later associated with the lawgiving (Wellhausen 1957:342). More importantly for Wellhausen was the notion that P linked the narrative to lawgiving. These conclusions would set the ground for subsequent studies on the Sinai pericope.

Von Rad (1992:189) built on Wellhausen's hypothesis, most notably the observation that the Sinai pericope was inserted between Exodus 18 and Numbers 10. Where Wellhausen relied on source criticism to come to his conclusion, Von Rad depended heavily on tradition history to advance Wellhausen's insights. Von Rad postulates an Exodus-conquest narrative (Ex 17, 18; Nm 10-14) which originated at a cultic festival that took place at Gilgal. He also notes a Sinai narrative (Ex 19-24; 32-34) which originated at Shechem. These two traditions developed separately and were only joined by the Yahwist. Von Rad's observations highlighted the role of the cult in Israel's traditions and also strengthened the idea that the law and narrative did not originally belong together. ${ }^{5}$

Perlitt (1969) also subscribe to the thesis that the Sinai pericope was inserted into a surrounding narrative. However, he disagrees with Wellhausen's proposal that the priestly writer was responsible for the theme of the law in the Sinai pericope. ${ }^{6}$ According to Perlitt (1969) the Sinai pericope has

\footnotetext{
4.The controversy and complexity of a source-critical approach to the sinai pericope is illustrated in the subsequent discussions on Wellhausen's approach. This is most prevalent in Exodus 19 and 24, where the discussion regarding sources is most complex. prevalent in Exodus 19 and 24, where the discussion regarding sources is most complex. 2003:51) and verses 3-8 to a Deuteronomistic editor, several critics view the whole 2003:51) and verses 3-8 to a Deuteronomistic editor, several critics view the whole
Chapter 19 as a later insertion, which functions as the introduction to the Sinai pericope Chapter 19 as a later insertion, which functions as the introduction to the Sinai pericope
(Childs 1974:360; Nicholson 1986:69; Ska 2006:29).The narrative of the theophany (vv. (Childs 1974:360; Nicholson 1986:69; Ska 2006:29).The narrative of the theophany (vv.
16-25) is interrupted repeatedly by Yahweh's summons of Moses to ascend the mountain. Noth (1962:160) ascribes verses $16 \mathrm{a}$ to J and $16 \mathrm{a}, 16 \mathrm{~b}, 17$ and 19 to E, while he assigns verses 20-25 to later additions. In contrast, Hyatt (1971:199-203) assign verses $16 \mathrm{a}$ and 18 to J, $16 \mathrm{~b}-17,19$ and 25 to $\mathrm{E}$, while $20-23$ is the work of a ' supplementer'. In terms of the important relationship between 19:3-8 and 24:3-8, the discussion follows the same pattern. Nicholson (1977:423-424) proposes 24:3-8 to be proto-Deuteronomic, while 19:3-8 is later-Deuteronomic (Nicholson 1986:169-172). Van Seters (1988:124-125) assigns 19:3-8 and 24:3-8 to a post-Deuteronomic Yahwist, while Ska (2006:92) sees 24:3-8 as a later insertion which ratifies the covenant.
}

5.Le Roux (1983:105-113), one of the scholars to whom this essay is dedicated, explained Von Rad's thesis to the South African academic community. He explained Von Rad's thesis to the South African academic community. He Yahwist then linked the Exodus tradition with Sinai and transposed the laws (which Yahwist then linked the Exodus tradition with Sinai and transposed the laws (which originated elsewhere) into the Sinai pericope. The Deuteronomist expanded the
narrative and finally the priestly writer used the Sinai pericope to project the ark narrative and finally the priestly writer used the Sinai pericope to project the ark and tabernacle into Israel's history in order to designate Sinai as the place where the cult was established. Importantly, Le Roux notes that the present form of the authentic account -- only a series of interpretations' (Le Roux 1983:112).

6.Blenkinsopp (2004:159) argues that the Sinai-pericope consists of priestly and Deuteronomistic material that was blended together. Dozeman (1989a:37-66, 87-144), on the other hand, makes a case for priestly and non-priestly material. According to this proposal, the priestly redaction provides the narrative context for According to this proposal, the priestly redaction provides the narrative context for
the P legislation. The priestly history relays the revelation to Mount Sinai while also describing the divine descent to the top of the mountain. The rest of the narrative is all non-priestly in nature. The consequence of this is that the P historian emphasises all non-priestly in nature. The consequence of this is that the P historian emphasises the role of Moses as mediator between God and his people by highlighting
that Moses alone was present at the top of the mountain with Yahweh. undergone some notable Deuteronomic/Deuteronomistic editing. Nicholson (1973, 1982:54-69), as well as Blum (1990:47-53), ${ }^{7}$ reiterated this position in subsequent studies. ${ }^{8}$

Schmid (2016:129-153) summarises much of the abovementioned theories in a paper dedicated to the investigation of the Divine Law in the neo-Babylonian period. ${ }^{9}$ He refers to the notion of the Sinai pericope as an insertion into the surrounding narrative but goes further to propose the development of the Divine Law in Israel's history. Importantly, Schmid (2016) notes that these law sections have undergone some redaction. ${ }^{10}$ Schmid builds on the works of Otto (2012), Levinson (1997) and Morrow (1995) who argue that the Covenant Code forms the nucleus of the Sinai pericope. ${ }^{11}$ They take this theory further by proposing that the earliest form of the Covent Code originated in pre-exilic times, more specifically in the late 8th and early 7 th centuries BCE. The Covenant Code, which originally formed part of the prophetic emphasis on social justice, was later transformed into legal stipulations. Schmid (2016) bases this hypothesis on the fact that the social situation in pre-exilic Judah resulted in major economic shifts, which in turn gave birth to a prophetic message and exhortation to care for the poor and disadvantaged.

On how Yahweh has eventually become the lawgiver, he urges our attention to the solarisation of Yahweh. Schmid (2016:144-147) proposes that Yahweh became associated with Jerusalem, and Jerusalem in turn became a symbol for sun worship. In the Ancient Near East, the sun-god was synonymous with justice and lawgiving. Jerusalem and

7.Blum (1990) proposes this as part of a detailed study on the composition of the Pentateuch. He designates a priestly composition (KP) and a Deuteronomistic composition (KD). According to this thesis, Genesis $12-50$ and the books of Exodus to Numbers were first integrated in a Deuteronomistic composition. Genesis 1-11 formed part of the priestly composition and was added to the Pentateuch by Deuteronomistic editors.

8.Patrick (1977:155-157) designates the narrative of the Sinai pericope to preDeuteronomistic redactors. Phillips (1984a:39-52, 1984b:282-294) takes this argument further by assigning the final form of the Sinai pericope to protoDeuteronomists who attempted a reform by combining the laws of the Decalogue and the Covenant Code. Earlier I referred to Nicholson who assigned Exodus 19:3-8 and $24: 3-9$ to late- and proto-Deuteronomistic redaction respectively. Phillips considers $19: 3-8$ and $24: 3-8$ to be part of the same proto-Deuteronomistic redaction. He dates this activity to the reign of king Hezekiah. On the topic of the proto-Deuteronomist, see the valuable contribution by Ausloos (2013:531-558).

9.In order to place the idea of God as lawgiver in the neo-Babylonian time, Schmid focuses on several arguments that point to the fact that the Pentateuch presupposes the fall of Jerusalem. He discusses four arguments: The Pentateuch as exilic document, the Pentateuch as republican document (as opposed to a monarchical document), which can either point to a pre-monarchial or a post-monarchial exilic date. In Schmid's opinion, the latter is more likely. He also argues that the concept of God as lawgiver is a late development is Israel's religious history (hence, the title of God as lawgiver is a late development is Israel 's religious history (hence, the title of his essay 'Divine Legislation in the Pentateuch in its Late Judean and NeoBabylonian Context'). Finally, he discusses the prevalence of Standard Biblical Hebrew in the Torah, which leads several scholars to point to the Torah as pre-exilic concept. Schmid, however, found that this argument is inconclusive and argues that we cannot date texts on this basis alone. In short, the idea God as lawgive (the overwhelming theme of the Sinai pericope) is a post-exilic concept. This has enormous consequences for the study and interpretation of the Sinai pericope.

10.According to Schmid (2016:147), the core passages of the Covenant Code were written in the third person. There is no Divine speaker associated with these passages. Some of the laws that form the Covenant Code are written in the first person address, while others are written in the second person address. The concept of the Covenant Code as a Divine address probably resulted from the passages in the Covenant Code which were written as second person, or even as first person address. Schmid leans heavily on the work of SchwienhortsSchönberger (1990), who argues that the Covenant Code originated and developed from smaller from smallo punishment (Ex 21:12-17), the stipulations of bodily injuries (Ex 21:18-32) and the
stipulations regarding objects (Ex 21:33-22:14).

11.This is confirmed by Blum (2011:295). However, Levin (1985:165-191) disagrees and posits the Decalogue as the nucleus of the Sinai pericope. 
Mount Zion eventually became associated with Mount Sinai, and in this process Yahweh became the lawgiver at Mount Sinai. As noted above, Schmid wrote this essay in order to explain the concept of Yahweh as lawgiver in the neoBabylonian time. In the process, he confirms many of the concepts described in this part of the current article. He notes the insertion of the Sinai pericope into the narrative as well as the tension between law and narrative within the Sinai pericope. On a methodological level, he confirms reliance on diachronic tools to explore the Sinai pericope.

The following provisional conclusions are in order:

1. Most scholars react to the tension between law and narrative in the Sinai pericope by postulating that the Sinai pericope was inserted into a surrounding narrative.

2. Consequently, law giving cannot be a part of original narrative. Wellhausen (1957) represents the extreme position in this regard when he commented the original narrative only told of an encounter with God on the mountain. ${ }^{12}$

3. The supposed redactional composition and growth of the Sinai pericope have forced scholars to study the Decalogue and the Covenant Code as separate law entities.

\section{Sinai pericope (Ex 19-24) as a cohesive literary unit}

Several scholars choose to approach the Sinai pericope as a literary unity, in sharp contrast to those who approach it as an interpolation. These scholars are quite aware of the several literary issues in the pericope, especially with regard to chronology. Nevertheless, they choose to interpret these texts from a synchronic perspective and therefore they tend to focus on literary techniques to explain the various narrative disruptions. In terms of the scope of this essay, these scholars see no tension between the law and narrative in the Sinai pericope. In fact, they view the relationship or link between law and narrative as the key to interpreting the Sinai pericope. According to Cover (1995:95-172) the law forms and determines the surrounding narrative. Most scholars take the opposite view and argue for the importance of the narrative, which gives the law its role in the Sinai pericope. The third category of scholars proposes a more integrated relationship between the law and the narrative. Stahl (1995) takes the concept of co-existence of different genres in the novel a step further by applying this to the Sinai pericope. This means that the law given by God and the people's response should not be treated separately (Stahl 1995:11-26). ${ }^{13}$ Joo (2016) also pleads for tighter integration between the law and the narrative, and base this on a careful analysis of the structure of the Sinai pericope. Sarna (1991:102) summarises this approach in arguing that the Covenant Code could not be viewed separately from the surrounding narrative.

12.Levin (1985:165-191) disagrees with this proposal and notes that the narrative does not make sense without law giving, a point that Oswald (2010:122) confirms and appreciates.

13.Fokkelman (1987:56-65) notes that the legal corpus corresponds to the narrative in terms of theme and therefore could not be separated. He also denotes the lega corpus as God's spoken word. The narrative is classified as enactments of God and corpus as God's spoken word. The narrative is classified as enactm
therefore should be read in conjunction with the legal corpus.
He notes that the Covenant Code is framed by narratives and dislocating it from those narratives would devaluate the Covenant Code. In short, although the synchronic approach to the Sinai pericope is prevalent today, the relationship between the law and the narrative remains a contentious and complex issue.

I will now turn my attention to the several approaches that define the synchronic approach to the Sinai pericope. It is reiterated that the chronology of the text is the primary issue. Scholars who tend to follow the synchronic way to make sense of the text, employ different techniques to explain, or even to explain away, the chronological issues.

\section{Chronological reconstruction}

Cassuto's (1961:223-315) attempt to unravel the chronological issues in the Sinai pericope involves reconstruction of the events based on stylistic devices prevalent in ancient literature. Although it is confusing to determine the number of Moses' ascents in Exodus 19, Cassuto (1961) supposes a single narrative sequence. He unravels the chronology in the following way:

1. In Exodus 19:3, Moses ascends the mountain. In Exodus 19:7, Moses descends in order to deliver the words of God to the people.

2. Exodus 19:3b suggests another ascend of the mountain. In Exodus 19:14, he descends again to prepare the people for theophany.

3. In Exodus 19:20, in reaction to God's arrival on top of the mountain, Moses ascends to receive an admonition. In Exodus 19:25, he descends to warn the people as God commanded him.

4. God summons Moses in Exodus 19:20b, and therefore he ascends in 19:20c. God commands him to talk to the people (Ex 19:24) and therefore he descends in Exodus 19:25. Another ascend with Aaron is suggested in Exodus 19:24b.

Cassuto's (1961) approach becomes clearer in his treatment of Exodus 24. He proposes that Moses is still on the mountain which he ascended in Exodus 20:20, when he receives the commands in Exodus 24:2. In Exodus 24:3, Moses descends to explain the Book of the Covenant to the people. Joo (2016:62) rightly notes that Cassuto (1961) did not mention the ascent in Exodus 19:19b. Furthermore, he asserts that Cassuto's (1961) reconstruction of the events in linear time is not satisfactory. He rightly judges the chronology to be more complex than Cassuto's reconstruction demands. Two important consequences emerged from Cassuto's (1961) work. In the first place, subsequent scholars would focus more on spatial time instead of linear time in order to unravel the knots of Exodus 19-24. Secondly, the focus would shift away from the attempts to unravel the chronology. Instead, scholars would focus on Moses' role as mediator in the Sinai pericope.

\section{Rhetorical techniques}

Watts (1999) presents an approach intended to interpret the Sinai pericope by rhetorical analysis. The starting point for 
Watts is the suggestion that Moses' role of a mediator in Exodus 20:18-21 represents a narrative interlude which aims to link the Decalogue and the Covenant Code. Watts also notes that Exodus 20:18-21 contains a retrospect of God's salvation.

Furthermore, Watts (1999 15-16, 49-52) argues that the Sinai pericope is defined by a list-narrative. He defines a listnarrative as a stereotyped rhetorical strategy which is not only important for interpreting the Sinai pericope but the whole of the Pentateuch. As noted earlier, the narrative plays an important role in Watts's reconstruction because the narrative not only encloses the law sections but also influences the law sections and determines their literary shape (Watts 1995:543). He bases this on the hypothesis that the law was intended for public reading. Apart from the public readings, the law was also intended to be read as the Torah. According to Watts, this is another reason why the law was embedded in the narrative.

In order to describe Watts's (1999) approach in more detail, it is necessary to understand his emphasis on Yahweh's direct speeches which focus on God's past deeds of salvation. Furthermore, he also draws attention to the passages which underscore the covenant obligations. These direct speeches play an important part in the Sinai pericope. He goes further by postulating that Exodus 20:18-21 forms an interlude between the two law corpora, the Decalogue and the Covenant Code, respectively. This interlude portrays Moses as a mediator between God and his people. It also depicts Moses as law giver, on the people's behest. In Watts's words, this passage 'legitimises Yahweh by virtue of his past deeds of salvation, it also highlights the people's obligations and legitimises Moses' role as mediator between God and his people' (Watts 1999:50).

Watts (1999) made a significant contribution by highlighting the blend of law and narrative as a rhetorical strategy. Other scholars would follow his footsteps and focus on rhetorical strategies to explain the law and the narrative in the Sinai pericope.

\section{Resumptive repetition techniques}

Sprinkle (1994) uses resumptive repetition to prove the inner cohesion and unity of the Sinai pericope. Resumptive repetition assumes that a narrative tells a story and later resumes this story by expanding it and telling it from a different perspective. According to Sprinkle, the problem lies with the reader who attempts to read the two stories in chronological order, while it is not intended to be read chronologically. Sprinkle uses this technique to argue that the Covenant Code functions as a resumptive repetition of the Decalogue. Furthermore, the events of Exodus 19:21-25 is to be read on the same plane as Exodus 24:3, where Moses stays on the mountain with God after receiving the Covenant Code. This also gives Sprinkle (1994) the opportunity to present as a chiastic structure to the Sinai pericope as follows:

\author{
A: Narrative - covenant offered (Ex 19) \\ B: General regulations - the Decalogue (Ex 20:1-17) \\ C: Narrative - people's fear of God (Ex 20:18-21) \\ B: Specific regulations (Ex 20:22-23:33)
}

A: Narrative - covenant consummated (Ex 24)

\section{Spatial-form techniques}

Dozeman (1989b:87-100) suggests that the redactional activity of the Sinai pericope includes several spatial-form techniques. This means that the characters of Yahweh, Moses and the people, as well as the setting of the mountain, are the primary force of the Sinai pericope. Characters and settings are therefore more important than chronology. According to Dozeman, the vertical movement of Moses between Yahweh and the people (embodied in various ascents and descents) becomes the way to interpret the covenant between Yahweh and his people. This empowers Dozeman to make sense of the chronology of the pericope. The prophecy of Exodus 19:9 (that the people hear God's words and will believe Moses' account) is realised in Exodus 20:18 when they see the effects of the theophany in the smoke, thunder and lightning. The effects of the theophany result in the people's fear and therefore they ask Moses to mediate between them and Yahweh. Dozeman's approach is also evident in his treatment of Exodus 19:1-2 (generally assumed to be a priestly text). Dozeman finds two repetitions in these verses and links them to another repetition in Exodus 19:2b-3a. The third repetition refers to the 'Mountain of God' tradition. This repetition then represents a pre-exilic account of Yahweh's manifestation at a cosmic mountain (Dozeman 1989b:91). The spatial technique is now used to override the temporal narrative sequence and the Yahweh is now portrayed as on the mountain, while the people are on the bottom of the mountain. This has significant canonical meaning for Dozeman (1989b:92) because it links the wilderness tradition with the Mountain of God tradition and amplifies the role of Mount Sinai, and therefore the law, in the Sinai pericope.

Odimuko (2016:127-137) follows Dozeman (1989b) in this regard. He describes the mountain setting where Moses, Aaron and others appear before Yahweh in the following way (Odimuko 2016):

The other individual scenes are parts of the narrative, which are arranged around this centre, and either occur simultaneously with the central mountain setting or with the other parts of the narrative.(p. 136)

Furthermore, he suggests that Exodus 19:16-25 forms the summary or synopsis of the Sinai pericope. All the events which follow: the Decalogue (Ex 20:1-17), the reaction of the people (Ex 20:18-20) and the Convenant Code (Ex 20:22 - 23:33) occur at the same time and aim to expand the synopsis of Exodus 19:16-25. Odimuko's (2016) approach is actually a combination of resumptive repetition and spatial-form technique. 
Joo (2016:139-140) focuses on the use of analepsis and prolepsis to make sense of the narrative sequence in the Sinai pericope. ${ }^{14}$ He suggests that Exodus 20:18-21 functions as analepsis (looking back at the first three narrative units) and prolepsis (looking forward to final narrative unit (Ex 24:1-11). The analepsis recounts the theophany and covenant proposal, while the prolepsis dominates the Decalogue and Covenant Code in order to explain how it is ratified. Importantly, Joo sees no tension between the law and the narrative and concludes that the mixture of law and covenant is prevalent in the Pentateuch. Joo concludes that the theme of the God of compassion binds the Sinai pericope together.

\section{Sinai pericope as a political constitution}

Oswald (1998) suggests a viewpoint that integrates law and narrative and points to the installation of a judicial system in pre-exilic Israel. Oswald's contribution is treated at this time because he integrates the law and the narrative in the Sinai pericope in a unique and coherent way. Nevertheless, Oswald (1998) approaches the Sinai pericope from the lens of redaction history. Oswald presents a comprehensive study on the redactional history of the Sinai pericope, where he postulates four redactional stages. The first layer is a non-priestly layer that originates from the land of Judah after 587 BCE. This layer constitutes a programmatic renewal of Israel. The second layer contains the 'Mountain of God' narrative and forms part of an 'Exodus-Mountain of God' narrative that aims to create solidarity amongst the people. The Covenant Code forms the judicial basis, while the Decalogue was added later. The third layer presents the covenant as opposition to hegemonic claims and introduces an egalitarian concept of society. In this layer, every member of the society is called a priest. Finally, the 'Exodus-Mountain of God' narrative became part of the Deuteronomistic history that stretches from the book of Exodus to 2 Kings. To take a step back, the original nonpriestly layer of the Sinai pericope was added to the original Exodus story (Ex 1-14).

Oswald (2010:121-135) dates the basic narrative of the Sinai pericope in the late pre-exilic period when the people had to reorganise their society in a non-monarchic, semiautonomous system. Oswald proposes that the fall of the Davidic dynasty (6th century BCE) led to the notion of selfrule. The office of the king had no place in this semiautonomous concept of a citizen-state. The Mountain of God narrative is an attempt to create this new political system in Judah. Therefore, the Decalogue and Covenant Code serve as the constitution of this new political order. ${ }^{15}$ Oswald (2010:129) notes that the people's resolution in Exodus 24:3

\footnotetext{
14. Nevertheless, he is open to resumptive repetition in the Exodus 20:18-21 between the Decalogue and the Covenant Code, in what he defines as the fourth literary unit (Joo 2016:139).

15.According to Oswald (2010:128), the broad range of laws present in the Covenant Code (cultic, laws of altar, festival calendar, laws pertaining to slaves, laws regarding the rights of the disadvantaged, Sabbath laws) points to a constitution. He also the rights of the disadvantaged, Sabbath laws) points to a constitution. He also
notes that other scholars define the Decalogue as constitution, but not the Decalogue and the Covenant Code as suggested by Oswald (2010).
}

makes this constitution a binding law. ${ }^{16}$ The only place where we find the people's participation in a constitution is in the model of the Greek cities, of which the earliest accounts are dated in the 5th century BCE. The earliest form of the Mountain of God narrative recounts a time where there was no king, and the people organised their society in a form of self-rule. According to Oswald (2010:133), the book of Deuteronomy was based on the same political concept. ${ }^{17}$

This unique approach helps Oswald (2010) to understand the law and narrative sections in the Sinai pericope. According to his model, the two concepts belong together. The narrative legitimises the law, while the law provides the context for the narrative.

\section{Eckart Otto's approach to the Sinai pericope}

The Sinai pericope confronts the attentive reader with several literary issues. These include the first and foremost the question of whether the Sinai pericope originated independently and was integrated later into a broader narrative framework. There is also the question regarding the composition and inner cohesion of the Sinai pericope. The several chronological issues point to a complex redaction history. Furthermore, there is the question of the relationship between the two main legal corpora, the Decalogue and the Covenant Code. While the first part of this article focussed on the different approaches to these problems, now Eckart Otto's contribution and attempts to make sense of the literary issues underlying the Sinai pericope are discussed.

Otto's (2013a:211-250) understanding of the composition of the Sinai pericope forms an integral part of his hypothesis on the origin of the book of Deuteronomy, which in turn leads him to present a hypothesis on the composition of the Pentateuch. Otto's Pentateuch theory is not only relevant on a literary level, his studies also result in a unique proposal regarding methodology and hermeneutics. In terms of the composition of the Sinai pericope, Otto regards the Covenant Code as the nucleus of the Sinai pericope. He also regards the Covenant Code to have originated as independent collections of laws which were thematically linked, for instance, the laws on bodily injuries (Ex 21:18-32) and the laws on objects (Ex 21:33-22:14). The earliest laws of stipulations of the Covenant Code were not associated with a Divine address. The concept of the laws as Divine laws were influenced by the textual frame of Exodus 20:24-26 and 22:17-26, which were written in the second and first-person forms. The final redaction of the Covenant Code included the laws that frame the Covenant Code (Ex 21:2-11; 23:10-12). These laws formed part of a law of Divine privileges or Privilegrecht. In these passages, the emphasis falls on the care of the poor, including

16.0 swald (2010:129) points out that neither God nor Moses imposes this law on the people. Moses relays the ordinances to the people and they play the decisive role in adopting it as constitution 'with one voice' (Ex 24:3).

17.In Deuteronomy 16:18 we find references to local judges and officers who are appointed by the people. We also find references to elders (Dt 5:23; 31:9.28) who represent the people. 
orphans and widows (Kratz 2000:147). This emphasis on social issues not only points to the 8 th and early 7 th centuries where social injustices were associated with that period (Otto 1988:69-71) but it also shows some relation to the prophetic call to justice in a world of injustice.$^{18}$ In other words, the laws of divine privilege bind all the originally independent laws and stipulations into a divine address. Already, this is a departure from the classic Wellhausen scheme where the concept of law originated late in Israel's history. According to Otto's reconstruction, the Covenant Code not only initiated the creation of the pre-exilic book of Deuteronomy but it also gave rise to the composition of the Pentateuch. In order to grasp the full intent of Otto's reconstruction, one must understand the relationship between the Covenant Code and the book of Deuteronomy.

Otto proposes that the pre-exilic book of Deuteronomy (6:4-5; $12: 13-27 ; 13: 2-12 ; 14: 22 ; 15: 23 ; 16: 1-18 ; 18: 5^{*} ; 19: 2-13 *, 15$; $21: 23 ; 22: 1-12 *, 13-29 ; 23: 16-26 ; 24: 1-4,6 ; 25: 4 *, 5-12 ; 26: 2-$ $13,20-44)$ revises and eventually supplements the Covenant Code. ${ }^{19}$ This pre-exilic book of Deuteronomy did not contain any reference to Moses, nor did it have any relation to the Horeb and Moab covenants. Deuteronomy 12 and 13 originally functioned as the principal regulations of laws (Hauptgebot) and corresponded with the altar law of Exodus $20: 24{ }^{20}$ The reason why the sequence of laws differs in Deuteronomy is due to the fact that laws in Deuteronomy were influenced and arranged by the motif of cult centralisation (especially Dt 12$).{ }^{21}$ Once again, it is important to notice that the Deuteronomy supplemented the Covenant Code and serves as the legal interpretation of the Covenant Code. In other words, the Covenant Code and the pre-exilic book of Deuteronomy were meant to be read together. Otto (2013b:210-250) gives a detailed explanation of this process, but for the purpose of this article, an example is referred to. The centralisation laws in Deuteronomy 12 become a hermeneutical key for understanding the altar law in Exodus 20:24-26. In Deuteronomy 12, the expression $b^{e}$ kal hammaqôm ${ }^{a}$ saer azkîr aet $s^{e} m \hat{\imath}$ is ambiguous and could be read in two ways. In the pre-Deuteronomic Covenant Code (Ex 20:24), the important sentence $b^{e} k a l$ hammaqôm ${ }^{a}$ saer azkîr aet $s^{e} m \hat{\imath}$ could be translated in the context of a distributive meaning as 'in each place', but the translation and interpretation of $b^{e} k a l$ hammaqôm with 'in all the place' places

18.Schmid (2016:150) points to some convincing similarities between Exodus $22: 24-26$ and Amos 2:6-8, where the prophetic book emphasises the need for social justice.

19.Levinson (1997) and Stackert (2007) suggest the opposite, namely that the book of Deuteronomy intends to replace the Covenant Code. However, it becomes difficult to explain why the Covent Code was kept in the Pentateuch if it was meant to be replaced.

20.Levin (2000:131-132) disagrees in this regard. Although he also proposes that some parts of the Covenant Code are pre-exilic and function as source for the Deuteronomic laws of asylum and manumission, he suggests that the altar law is post-exilic polemic against cult centralisation. Van Seters (2003) suggests that the Covenant Code is a unified composition and should be dated in the postexilic period. This position proved too extreme and controversial to be taken seriously.

21.According to Otto, this reinterpretation of the Covenant Code took place against an anti-Assyrian background. Otto finds in Deuteronomy 13:1 (loyalty oath) and 28:20-44 (blessings and curses) traces of Assyrian loyalty oath concepts. In other 28:20-44 (blessings and curses) traces of Assyrian loyalty oath concepts. In other words: Deuteronomy used the Assyrian royal motifs to create
Assyrian motif where the people are called to serve Yahweh alone. the law in the contexts of the cult centralisation of the preexilic book of Deuteronomy. In other words, the Deuteronomic authors read the altar law of the Covenant Code and the centralization law of the book of Deuteronomy as a legal unit. The Covenant Code becomes the source of legitimising the programme of cult centralisation.

The methodological and hermeneutical approach of Otto's (1994) is underlined in his treatment of the Covenant Code. His method suggests that the Covenant Code and pre-exilic books of Deuteronomy were meant to be read synchronically. Whereas the modern reader will no doubt notice the obvious tension in the two legal corpora, the authors prevented this ambiguity by including both in a system of self-interpretation. This approach is also illustrated in Otto's treatment of the other content of the Sinai pericope, namely the Decalogue. According to Otto's reconstruction, the Decalogue was transferred from Deuteronomy 5 to Exodus 20 (Otto 1994:230-233). The Decalogue in Exodus 20 exhibits an older version of the Decalogue than Exodus 20, but Deuteronomists already used and revised this older Decalogue in Deuteronomy 5. Therefore, the Decalogue in Exodus 20 contains parts which are older than Deuteronomy 5 as well as parts which are post-Deuteronomistic (Otto 1994:208-219, 2000:245-246). Once again, the same pattern emerges; the scribes who revised and edited the book Deuteronomy included their sources in the process, in this case, Exodus 20.22 The Decalogue in Deuteronomy becomes an interpretation of the Decalogue in Exodus 20.

This article explained the several approaches to the mixture of law and narrative in the Sinai pericope (Ex 19-24). Several synchronic approaches were discussed. Proponents of this approach aim to read the law and the narrative as a literary unity. Diachronic approaches, on the other hand, aim to prove that the legal sections were interpolated into a broader narrative. This leads to the conclusion that the legal sections are to be dated very late, preferably in a post-exilic context. Otto's approach takes the diachronic approach very seriously, but he goes further by proposing a synchronic link between the Sinai pericope and the pre-exilic book of Deuteronomy. This approach reaches beyond the impasse created by proponents of either the diachronic or synchronic approaches. Of course, Otto's hypothesis is not the only creative contribution. The proposal offered by Oswald (1998) is also very ingenious, but the fact that Otto attributes the composition of the Covenant Code to the social injustice of the late 8th and early 7th centuries BCE, makes it a very plausible possibility. Furthermore, Otto's contribution proposes the symbiotic relationship between the Sinai pericope and the pre-exilic book of Deuteronomy, which creates new possibilities for the role of legal codes in the formation of the Pentateuch.

22.0tto (2013b:384) finds the same pattern in the discussion regarding the relationship between the spy stories in Deuteronomy 1:19-46 and Numbers $13-$ relationship between the spy stories in Deuteronomy $1.19-46$ and Numbers $13-$ 14. He proposes that Deuteronomy uses a pre-Deuteronomistic version of the story. He finds that Numbers 13-14 used the Deuteronomistic version of Deuteronomy. Subsequently, the authors of the Pentateuch and Hexateuch edactions also included the source of their source, namely the pre-Deuteronomistic story that was taken up in Deuteronomy. This pattern is repeated in the Sihon-Og stories (Dt 2:24-3:11/Nm 20-21/Jdg 11:12-18) as well as the story of the golden calf (Dt 9:9-10:11/Ex 32/1 Ki 12:26-30/2 Ki 17:21-23). 


\section{Conclusion}

The study of the Pentateuch remains a complex and everevolving endeavour. Otto has stimulated the discussion regarding the composition of the Sinai pericope in a very unique way. He has underlined the importance of law to understand the growth of the book of Deuteronomy and consequently the Pentateuch. His methodological mixture of diachrony and synchrony has created some much needed stimulus in the ongoing Pentateuch debate. ${ }^{23}$

To summarise, Otto also confirms the viewpoint that the Covenant Code and the Decalogue were inserted into the Sinai pericope. Otto, however, is not concerned about the literary tension which resulted because of the interpolation as well as the subsequent redaction. He offers a synchronic model in order to read the Sinai pericope and the book of Deuteronomy together. ${ }^{24}$ This enables Otto to transfer this model to explain the composition of the Pentateuch. Otto's contribution can best be described with a variation on a wellknown dictum: 'It embodied what came before, illuminated what came after'.

\section{Acknowledgements Competing interests}

The author declares that he has no financial or personal relationships that may have inappropriately influenced him in writing this article.

\section{Author's contributions}

J.M.W. is the sole author of this research article.

\section{Ethical considerations}

This article followed all ethical standards for a research without direct contact with human or animal subjects.

\section{Funding information}

This research received no specific grant from any funding agency in the public, commercial or not-for-profit sectors.

\section{Data availability statement}

Data sharing is not applicable to this article as no new data were created or analysed in this study.

\footnotetext{
23.See, for instance, Kilchör's (2015) approach to the legal corpora in the Pentateuch, which challenges that of Otto in a stimulating way.

24.The broader outline of Otto's reconstruction of the composition of the book of Deuteronomy is in order at this point. Apart from the pre-exilic book of Deuteronomy, he also proposes an exilic and post-exilic redaction. In the case of the exilic redaction, Otto suggests that the Decalogue in Deuteronomy 5 formed the basis for the redaction of the pre-exilic book of Deuteronomy. The covenan made at mount Horeb became the cornerstone of Israel's commitment to Yahweh. Deuteronomy 5-12 served as an application of Divine Law for living as the new Israel in the Promised Land (Otto 2013a.230). The Decalogue formed the now part of a Horeb redaction, which amplified the idea that the law is also importan for those who reconstructs a Moab redaction, where the second generation in exile supplanted the Horeb redaction with narrative Promised Land. This underlines their view that a return of the Promised Land was eminent.
}

\section{Disclaimer}

The views and opinions expressed in this article are those of the author and do not necessarily reflect the official policy or position of any affiliated agency of the author.

\section{References}

Ausloos, H., 2013, 'The "proto-Deuteronomist": Fifty years later', Old Testament Essays 26(3), 531-558.

Blenkinsopp, J., 2004, Treasure Old \& New: Essays in the Theology of the Pentateuch, Eerdmans, Grand Rapids, MI.

Blum, E., 1990, Studienzur Komposition des Pentateuch, Beihefte zur Zeitschrift für die alttestamentliche Wissenschaft (BZAW) 189, de Gruyter, Berlin.

Blum, E., 2011, 'The Decalogue and the composition history of the Pentateuch', in T.B. Dozeman, K. Schmid \& B.J. Schwartz (eds.). The Pentateuch. International perspectives on current research, pp. 289-301, Mohr Siebeck, Tübingen.

Boecker, H.J.,1980, Law and the administration of justice in the Old Testament and ancient east, transl. J. Moiser, Augsburg, Minneapolis, MN.

Childs, B.S., 1974, The book of Exodus. A critical theological commentary, The Old Testament Library, Westminster Press, Philadelphia, PA.

Cassuto, U., 1961, A commentary on the book of Exodus, transl. I. Abrahams, Magnes, Jerusalem.

Cover, R.M., 1995, 'Foreward: Nomos and Narrative', in M. Minow \& M. Ryan (eds.), Narrative, Violence and the Law: The Essays of Robert Cover, pp 95-96, 101-102, University of Michigan Press, Ann Arbour, MI.

Dozeman, T.B., 1989a, God on the mountain: A study of redaction, theology and canon in Exodus 19-24, Society of Biblical Literature Monograph Series, Scholars Press, Atlanta, GA.

Dozeman, T.B., 1989b, 'Spatial-form in Exodus 19:1-8a and in the larger Sinai narrative', Semeia, vol. 46, 87-100.

Eissfeld, O., 1965, The Old Testament: An introduction, transl. P.R. Ackroyd, Harper \& Row, New York, NY.

Fokkelman, J.P., 1987, 'Exodus', in R. Alter \& F. Kermode (eds.), The literary guide to the Bible, pp. 56-65, Harvard University Press, Cambridge, MA.

Friedmann, R.E., 2003, The Bible with sources revealed, HarperCollins, San Francisco, CA. Hyatt, J.P., 1971, Exodus, New Century Bible (NCB), Attic, Greenwood, SC.

Joo, H.K., 2016, 'The God of compassion at Mount Sinai: A literary and theological interpretation of the tangled mix of law and narrative in the Sinai pericope (Exodus 19:1-24:11)', DPhil unpublished dissertation, Biblical Department, University of Toronto.

Kilchör, B., 2015, Mosestora and Jahwetora. Das Verhältnis von Deuteronomium 12-26 zu Exodus, Levitikus und Numeri, BZAR21, Harrassowitz, Wiesbaden.

Kratz, R.G., 2000, Die Komposition der erzählenden Bücher des Alten Testaments, UTB 2157, Vandenhoeck \& Ruprecht, Göttingen.

Le Roux, J.H., 1983, 'Exodus and Sinai according to Gerhard von Rad', Old Testament Essays 1, 105-113.

Levin, C., 1985, 'Der Dekalog am Sinai', Vetus Testamentum 35(1), 165-191. https:// doi.org/10.1163/156853385X00420

Levin, C., 2000, 'Das Deuteronomium un der Jahwist', in R.G. Kratz \& H. Spieckerman (eds.), Liebe und Gebot: Studien zum Deuteronomium, Forschugen sur Religion und Literatur des Alten und Neuen Testaments 190, pp. 121-136, Vandenhoeck \& Ruprecht, Göttingen.

Levinson, B.M., 1997, Deuteronomy and the hermeneutics of legal innovation, Oxford University Press, New York, NY.

Morrow, W.S., 1995, Scribing the center: Organization and redaction in Deuteronomy 14:1-17:13, SBL MS 49, Scholars Press, Atlanta, GA

Nicholson, E.J., 1973, Exodus and Sinai in history and tradition, Blackwell, Oxford.

Nicholson, E.J., 1977, 'Decalogue as direct address of God', Verbum et Ecclesia 27(4), 422-433. https://doi.org/10.1163/156853377X00285

Nicholson, E.J., 1982, 'The covenant ritual in Exodus xxiv 3-8', Verbum et Ecclesia 32 54-69. https://doi.org/10.2307/1518193

Nicholson, E.J., 1986, God and his people. Covenant theology in the Old Testament, Clarendon Press, Oxford.

Noth, M., 1962, Exodus: A commentary, The Old Testament Library, Westminster Press, Philadelphia, PA.

Odimuko, D.O., 2016, 'Making sense of the Sinai pericope: A synoptic reading of the Sinai pericope', All Nations University Journal of Applied Thought 5, 127-137.

Oswald, W., 1998, Israel amGottesberg: EineUntersuchungzur Literaturgeschichte der vorderen Sinaiperikope Ex 19-24 und deren historischem Hintergrund, OBO 159, Vandenhoeck \& Ruprecht, Göttingen.

Oswald, W., 2010, 'Early democracy in ancient Judah. Considerations on Exodus 18-24 with an outlook on Dtn 16-18', Communio Viatorum 52(2), 121-135.

Otto, E., 1988, Wandel der Rechtsbegründungen in der Gesellschaftsgeschichte des antiken Israel: eine Rechtsgeschichte des 'Bundesbuches' EX XX 22-XXIII 13, Brill, Leiden.

Otto, E., 1994, Theologische Ethik im Alten Testament, ThW 3/2, Kohlhammer, Stuttgart. 
Otto, E., 2000, Das Deuteronomium im Pentateuch und Hexateuch: Studien zur Literaturgeschichte von Pentateuch und Hexateuch im Lichte des Deuteronomiumrahmens, Forschungen zum Alten Testament 30, Mohr Siebeck,

Otto, E., 2012, Deuteronomium 1,1-4, 43, HThK.AT, Herder, Freiburg.

Otto, E., 2013a, 'The history of the legal-religious hermeneutics of the book of Deuteronomy from the Assyrian to the Hellenistic period', in A.C. Hagedorn \& R.G. Kratz (eds.), Law and religion in the Eastern Mediterranean: From antiquity to early Islam, pp. 211-250, Oxford University Press, Oxford.

Otto, E., 2013b, 'The books of Deuteronomy and Numbers in one Torah. The book of Numbers read in the horizon of the post-exilic Fortschreibungin the book of Deuteronomy: New horizons in the interpretation of the Pentateuch', in C. Frevel, T. Pola \& A. Schart (eds.), Torah and the book of Numbers, pp. 383-397, Mohr Siebeck, Tübingen.

Patrick, D., 1977, 'The covenant code source', Vetus Testamentum 27(1), 145-157. https://doi.org/10.1163/156853377X00410

Perlitt, L., 1969, Bundestheologie im Alten Testament, WMANT 36, Neukirchener Verlag, Neukirchen-Vluyn.

Phillips, A.C.J., 1984a, 'A fresh look at the Sinai pericope - Part 1', Vetus Testamentum 34(1), 39-52. https://doi.org/10.2307/1518202

Phillips, A.C.J., 1984b, 'A fresh look at the Sinai pericope - Part 2', Vetus Testamentum 34(3), 282-294. https://doi.org/10.1163/156853384X00205

Sarna, N.M., 1991, Exodus. The traditional Hebrew text with the New Hebrew translation, Jewish Publication Society Torah Commentary (JPSTC), Philadelphia, PA.

Schmid, K., 2016, 'Divine legislation in the Pentateuch in its late Judean and neoBabylonian context', in P. Dubovský, D. Markl \& J.P. Sonnet (eds.), The fall of Jerusalem and the rise of the Torah, FAT 107, pp. 129-153, Mohr Siebeck, Tübingen
Schwienhorts Schönberger, L., 1990, Das Bundesbuch. (Ex 20, 22-23, 33). Studien zu seiner Entstehung und Theologie, BZAW 188, de Gruyter, Berlin.

Ska, J.L., 2006, Introduction to reading the Pentateuch, transl. S.R. Pascale Dominique, Eisenbrauns, Winona Lake, IN.

Sprinkle, J.M., 1994, The book of the covenant. A literary approach, JSOT 174, JSOT Press, Sheffield.

Stackert, J., 2007, Rewriting the Torah. Revision in Deuteronomy and the holiness code, FAT 52, Mohr Siebeck, Tübingen.

Stahl, N., 1995, Law and liminality in the Bible, JSOT 202, Sheffield University Press, Sheffield.

Van Seters, J., 1988, 'Comparing Scripture with Scripture: Some Observations on the Sinai pericope of Exodus 19-24', in G.M. Tucker (ed), Canon, Theology and Old Testament Interpretation: Essays in Honor of Brevard S. Childs, pp. 11 . Fortress, Philadelphia, PA.

Van Seters, J., 2003, A law book for the Diaspora: Revision in the study of the Covenant Code , Oxford University Press, Oxford.

Von Rad, G., 1992, Theologie des Alten Testaments 1, Kaiser Verlag, Munich.

Watts, J.W., 1995, 'Public readings and Pentateuchal law', Vetus Testamentum XLV(4), 540-557. https://doi.org/10.1163/1568533952662270

Watts, J.W., 1999, Reading law: The rhetorical shaping of the Pentateuch, BS59, Sheffield Academic Press, Sheffield.

Wellhausen, J., 1894, Israelitische und jüdische Geschichte, Reimer, Berlin.

Wellhausen, J., 1899, The composition des Hextateuchs und der historischen Bücher des Alten Testament, Reimer, Berlin.

Wellhausen, J., 1957, Prolegonema to the history of Israel, transl. A. Menzies \& J.S Black, Meridian Books, New York, NY. 